\title{
Risk Assessment of Resources Factor in Affecting Project Time
}

\author{
Saiful Husin $\left(\mathbb{D},{ }^{1}\right.$ Abdullah Abdullah, ${ }^{2}$ Medyan Riza, ${ }^{2}$ and Mochammad Afifuddin ${ }^{2}$ \\ ${ }^{1}$ Engineering Doctoral Study Program, University of Syiah Kuala, 23111 Banda Aceh, Indonesia \\ ${ }^{2}$ Faculty of Engineering, University of Syiah Kuala, 23111 Banda Aceh, Indonesia \\ Correspondence should be addressed to Saiful Husin; saifulhusin@unsyiah.ac.id
}

Received 24 May 2018; Accepted 11 October 2018; Published 29 October 2018

Academic Editor: Luigi Di Sarno

Copyright (C) 2018 Saiful Husin et al. This is an open access article distributed under the Creative Commons Attribution License, which permits unrestricted use, distribution, and reproduction in any medium, provided the original work is properly cited.

\begin{abstract}
Some risk factors contribute to various adverse effects on project implementation, especially the construction project. Risk needs to be recognized by analyzing the relationship between frequency of risks occurrence and impacts that may arise regarding construction time completion. The superposition of frequency and impact will indicate the risk importance of various risk factors. This research, therefore, aimed to assess the risk importance in time aspects of construction implementation to the contractor as the project executor is associated with the project resource factors. The resource factors reviewed are related to construction labor, materials, and equipment. The object of the study observed is a large qualified contractor company in Aceh Province with experience in the construction field for more than 15 years. The selection of time constraints is linked to the conditions of the company under various situations in Aceh during this period, both during the period of political and military conflicts, in the postdisaster rehabilitation and reconstruction period, and in the post-rehabilitation and reconstruction period. Characteristics of contractors and risks emerging are observed from the results of questionnaires distributed as instrument of data collection. The three resource factors studied each consists of several risk variables. The use of variables in the questionnaire is determined from the test results related to the validity and reliability of these variables. Risk assessment results of the three factors in the research indicate that the frequency of events and the level of impact of each variable determine the magnitude of the risk importance value. The labor is a factor with higher frequency and intensity of impact than the other two factors of study. Therefore, these factors contribute significantly to the project's completion time.
\end{abstract}

\section{Introduction}

Implementing the construction projects is vulnerable to risks that affect project objectives. Some internal or external risk factors may affect project targets. Project risk can be sourced from resource factors, which includes labor, materials, and equipment.

Risks are likely or no and, if they occur, will have an impact on the project [1-5]. In the opportunity theory, the risk is the probability of unexpected conditions and all of consequences possibility for project delays or project failures [6-11]. Risks are the variable of activities or factors and, if they occur, will decrease the achievement level of project objectives, i.e., cost and performance [12-15]. From the above definition, it can be concluded that the risk is an occurrence of uncertainty with an absolute chance of a condition that leads to unfavorable consequences of project objectives. Furthermore, risks in the project are a result in unfavorable physical, schedule, and financial consequences for the achievement of project objectives, i.e., cost, time, and project quality $[12,13]$. Therefore, the risk is essential to manage risk project that can survive or perhaps optimize risk [12, 16-18].

The construction project implementers in Aceh Province face various risks over the past 15 years, such as the military and political conflicts of 2000-2004, postearthquake and tsunami rehabilitation and reconstruction in 2005-2009, and postrehabilitation and reconstruction in 2010-present [19]. These three periods provide different risk characteristics, both concerning the probability of the occurrence $[20-24]$ and the impact $[25,26]$ for the project implementer. The first period was the period when there was a conflict of interest between GAM (Free Aceh Movement) and the central government. In that period, many armed conflicts 
affected the security and safety [19]. Most contractors tend to refuse project work for security reasons. This condition could cause many projects, for both public and private sector investment running improperly. The second period is the period of rehabilitation and reconstruction, where the political conflict has decreased dramatically, and this was marked after signing peace memorandum on 15 August 2005 [19]. The number of construction works increased very high in this second period if compared to the previous period. The increase in employment is not proportional to the number of contractors and labors available in Aceh Province. The third period is the period in which the political and military conflicts have decreased, and the number of jobs declines drastically, or this condition is called as a normal condition until the current condition.

Risk assessment can be attributed to some factors and targets of a construction project consisting of cost, time, and performance. Previous research has indicated that various risk factors including factors related to project resources [20], external factors [21], managerial and operational factors [22], contracting and design factors [23], and financial and construction methods [24]. The potential for risk occurrence tends to be seen in the project resource factors associated with labors, and external factors related to government policy.

While associated with the impacts assigned to the project objectives, the studies that have been conducted are likely to see the impact on the cost aspects $[25,26]$. The assessment of risks to project completion time has not been explained. The risk assessment of time is required given that this element is one of the success indicators of a project achieving its objectives. Analyzing the time risk impact on a construction project is required related to our previous risk factors as in paper [20-26]. Considering the abovementioned conditions, this study is aimed at assessing potential risks that may arise from the timing of completion of a construction project. The risk assessment focuses on project resource factors comprising labor, material, and equipment factors.

\section{Materials and Methods}

2.1. Data Collection. This research uses primary data collected by using questionnaire instrument. The questionnaire contains some questions prepared to obtain information related to the characteristics of the respondent, the occurrence frequency rating, and the impact on the timing of completion of the construction. Risk factors associated with project resources include 7 variables of labor factor, 10 variables of material factors, and 17 variables of equipment factor (Table 1).

The selection of respondents is based on a contractor company that has been involved in construction work for the last more than 15 years. The number of companies involved in the questionnaire survey counted 15 companies out of a total population of 20 contracting companies with large qualifications. These data are based on the membership of the company at the Construction Services Development Agency 2016. The minimum respondent is the personnel of
TABLE 1: List of factors and variables of project resources [20, 25].

\begin{tabular}{|c|c|c|}
\hline $\begin{array}{l}\text { Resources } \\
\text { factors }\end{array}$ & $\begin{array}{l}\text { Variable } \\
\text { code }\end{array}$ & Variables \\
\hline \multirow{7}{*}{ Labor } & A1 & Low labor availability \\
\hline & A2 & The ability of the labor is lacking \\
\hline & A3 & The discipline of unfavorable labor \\
\hline & A4 & Low labor productivity \\
\hline & A5 & Less solid teamwork \\
\hline & A6 & Labor squabble \\
\hline & A7 & Strike the labor \\
\hline \multirow{10}{*}{ Material } & B1 & Increase in material prices \\
\hline & B2 & Delay in material delivery \\
\hline & B3 & Theft of material \\
\hline & $\mathrm{B} 4$ & Material quality is below standard \\
\hline & B5 & $\begin{array}{c}\text { The type and quantity of material are not } \\
\text { correct }\end{array}$ \\
\hline & B6 & $\begin{array}{c}\text { Damage of material on delivery and } \\
\text { storage }\end{array}$ \\
\hline & B7 & Limited material shelter \\
\hline & B8 & $\begin{array}{c}\text { The supplier cannot fulfill the material } \\
\text { order }\end{array}$ \\
\hline & B9 & $\begin{array}{c}\text { Planning and management of good } \\
\text { materials }\end{array}$ \\
\hline & $\mathrm{B} 10$ & Material handling \\
\hline \multirow{17}{*}{ Equipment } & $\mathrm{C} 1$ & Low capacity of equipment \\
\hline & $\mathrm{C} 2$ & Displacement of equipment \\
\hline & $\mathrm{C} 3$ & Late mobilization of equipment \\
\hline & $\mathrm{C} 4$ & Equipment is incomplete \\
\hline & C5 & Device damage \\
\hline & C6 & Unqualified of equipment inspection \\
\hline & $\mathrm{C} 7$ & Productivity and efficiency decreased \\
\hline & $\mathrm{C} 8$ & The additional cost of equipment rental \\
\hline & C9 & Fuel scarcity \\
\hline & $\mathrm{C} 10$ & Difficult to access for heavy equipment \\
\hline & $\mathrm{C} 11$ & $\begin{array}{l}\text { Planning and equipment management is } \\
\text { not good }\end{array}$ \\
\hline & $\mathrm{C} 12$ & Equipment maintenance costs are high \\
\hline & $\mathrm{C} 13$ & $\begin{array}{c}\text { Do not understand the procedure of using } \\
\text { equipment }\end{array}$ \\
\hline & $\mathrm{C} 14$ & $\begin{array}{c}\text { Not suitable equipment for working } \\
\text { conditions/field }\end{array}$ \\
\hline & $\mathrm{C} 15$ & Ownership of rental equipment \\
\hline & $\mathrm{C} 16$ & Ownership of rental-purchase equipment \\
\hline & $\mathrm{C} 17$ & Ownership of proprietary tools \\
\hline
\end{tabular}

the company at the middle managerial level, such as the director, manager, and senior engineer.

2.2. Questionnaire Testing. This questionnaire testing is conducted to ensure the data collection is valid and reliable to answer the research objectives. The instrument testing uses the validity test and the reliability test. The need for the validity test is to show the validity levels of an instrument by using the Pearson product moment correlation [27]. Pearson product moment correlation $(r)$ measures the linearity of two paired variables $x$ and $y$ for $n$ number of respondents. To determine whether or not a valid variable item uses the criteria, the following conditions were assumed:

(1) If $t \geq t_{\text {sig }}$, then the variables are declared as valid

(2) If $t<t_{\text {sig }}$, then the variables are declared as invalid 
The correlation was analyzed by using the formula in the following equations:

$$
\begin{aligned}
& r=\frac{n\left(\sum x y\right)-\left(\sum x\right)-\left(\sum y\right)}{\sqrt{\left\{n \sum x^{2}-\left(\sum x\right)^{2}\right\}}\left\{n \sum y^{2}-\left(\sum y\right)^{2}\right\}}, \\
& t=\frac{r \sqrt{n-2}}{\sqrt{1-r^{2}}}
\end{aligned}
$$

The reliability test $(r)$ is performed to ensure the reliability of instrument as the data collection tool by using Cronbach's Alpha (C-Alpha) analysis. An indicator of questionnaire feasibility is measured by the C-Alpha coefficient $\geq 0.6$. The significance level for the statistical test used is $5 \%$. The reliability test is performed using Equations (3)-(5) [28]:

$$
r=\frac{k}{(k-1)}\left[1-\frac{\sigma_{b}^{2}}{\sigma_{1}^{2}}\right],
$$

where $r$ = reliability of the instrument, $k=$ the total of question items, $\sigma_{b}^{2}=$ the variance of items, and $\sigma_{1}^{2}=$ the total score variance. The variance of items and the total variance are calculated by using Equations (4) and (5):

$$
\begin{aligned}
& \sigma_{b}^{2}=\frac{J k_{\mathrm{i}}}{n}-\frac{J k_{\mathrm{s}}}{n^{2}}, \\
& \sigma_{1}^{2}=\frac{\sum x t^{2}}{n}-\frac{\left(\sum x t^{2}\right)}{n^{2}},
\end{aligned}
$$

where $\sum x t^{2}=$ the total response of the respondents, $\sum x t^{2}=$ the square of total response, $J k_{\mathrm{i}}=$ the sum of squares of whole items, and $J k_{\mathrm{s}}=$ the total square of response.

\subsection{Analysis}

2.3.1. Analysis of Frequency Index (FI). Frequency index (FI) is used to assess the frequency of risk occurrences. The index is used as an indicator to explain the frequency of risk factors reviewed. The FI analysis is as follows [29]:

$$
\text { Frequency index }(\mathrm{FI})=\frac{\sum_{I=1}^{5} a_{i} n_{i}}{5 \mathrm{~N}},
$$

where $i=$ the index of the category, $a_{i}=$ the weight of the $i$-th response, $n_{i}=$ the total of respondent response for item $i$-th, and $N=$ the total number of respondents. The frequency index scale was made using a Likert scale with the criteria shown in Table 2.

2.3.2. Analysis of the Severity Index (SI). The assessment results of risk impact on project completion time are presented in the form of the severity index (SI). The severity index shows the impact index of the emergence of internal risk factors [29]. The index is an indicator of the magnitude of the impact of resources risk factors reviewed. The classification of the risk impacts of the severity index scales used in this study can be seen in Table 3. The severity index analysis [29] is done by using the following calculation formula:
TABLE 2: Criteria and rating scale FI [30].

\begin{tabular}{lcc}
\hline Qualification & Likert scale & Scoring scale \\
\hline Very rarely & 1 & $0.000 \leq$ FI $\leq 0.125$ \\
Rarely & 2 & $0.125<$ FI $\leq 0.375$ \\
Often enough & 3 & $0.375<$ FI $\leq 0.625$ \\
Often & 4 & $0.625<$ FI $\leq 0.875$ \\
Very often & 5 & $0.875<$ FI $\leq 1.000$ \\
\hline
\end{tabular}

TABle 3: Criteria and rating scale SI [30].

\begin{tabular}{lcc}
\hline Qualification & Likert scale & Scoring scale \\
\hline Very low & 1 & $0.000 \leq$ SI $\leq 0.125$ \\
Low & 2 & $0.125<$ SI $\leq 0.375$ \\
Medium & 3 & $0.375<$ SI $\leq 0.625$ \\
High & 4 & $0.625<$ SI $\leq 0.875$ \\
Very high & 5 & $0.875<$ SI $\leq 1.000$ \\
\hline
\end{tabular}

$$
\text { Severity index }(\mathrm{SI})=\frac{\sum_{I=1}^{5} a_{i} n_{i}}{5 N},
$$

where $i=$ the index of the category, $a_{i}=$ the weight of the $i$-th response, $n_{i}=$ the total of respondent response for item $i$-th, and $N=$ the total number of respondents. The severity index scale was made using the Likert scale with the criteria shown in Table 3.

2.3.3. Analysis of Risk Importance Index (RII). The risk analysis is completed by using the risk importance index (RII) analysis, as it is formulated in Equation (8). Risk importance is one method to measure the importance of risk based on the amount of occurrence (frequency) and impact (severity) that can be caused. This risk importance will be analyzed against per variable of the resource risk factors:

$$
\mathrm{RII}=\mathrm{FI} \times \mathrm{SI},
$$

where $\mathrm{FI}=$ frequency index of each risk variable and SI = severity index of each risk variable.

\section{Results and Discussion}

3.1. Respondents' Characteristics. Respondents' characteristics are divided into two, namely, the characteristics of personality and characteristics of the contractor, as shown in Tables 4 and 5 .

Data are collected from 15 respondents who were working in a contractor firm with great qualification domiciled in Aceh Province. Respondents of this study generally have a position as manager and director of the company with work experience between 2 and 4 years. Typically, the contractor has more than 15 years of experience in the field of construction and has handled a number of projects during the political conflict period, the rehabilitation and reconstruction period, and post-rehabilitation and reconstruction period, so it can be concluded that the contractors who are the respondents of this research understand project risks at all three periods. 
TABLE 4: Characteristic of respondents.

\begin{tabular}{lccc}
\hline $\begin{array}{l}\text { Category of } \\
\text { characteristic }\end{array}$ & $\begin{array}{c}\text { Characteristic } \\
\text { description }\end{array}$ & Frequency & $\begin{array}{c}\text { Frequency } \\
\text { relative (\%) }\end{array}$ \\
\hline Position in & Director & 5 & 33.3 \\
contractor firm & Manager & 7 & 36.67 \\
& Other & 3 & 20.00 \\
\hline \multirow{2}{*}{$\begin{array}{l}\text { Personal } \\
\text { experience }\end{array}$} & $>2-4$ years & 1 & 6.67 \\
& $>4-7$ years & 1 & 6.67 \\
\hline
\end{tabular}

TABLE 5: Contractor firms characteristic of respondents.

\begin{tabular}{lccc}
\hline $\begin{array}{l}\text { Category of } \\
\text { characteristic }\end{array}$ & $\begin{array}{c}\text { Characteristic } \\
\text { description }\end{array}$ & Frequency & $\begin{array}{c}\text { Frequency } \\
\text { relative }(\%)\end{array}$ \\
\hline \multicolumn{4}{c}{ Period of conflict } \\
& 1-3 projects & 3 & 20.00 \\
& $>3-6$ projects & 5 & 33.33 \\
& $>10$ projects & 4 & 30.00 \\
Total of & Period of rehabilitation reconstruction \\
contractor's & $1-3$ projects & 1 & 6.67 \\
projects & $>3-6$ projects & 5 & 33.33 \\
handled & $>6-10$ projects & 3 & 20.00 \\
& $>10$ projects & 6 & 40.00 \\
& Period of post-rehabilitation reconstruction \\
& $1-3$ projects & 2 & 13.33 \\
& $>3-6$ projects & 2 & 13.33 \\
& $>6-10$ projects & 5 & 33.33 \\
& $>10$ projects & 6 & 40.00 \\
\hline \multirow{2}{*}{ evpes of projects } & Building & 11 & 73.33 \\
ever handled & Wads and bridges & 14 & 93.33 \\
& Water constructions & 9 & 60.00 \\
\hline Average of & $<10$ billion & 2 & 13.33 \\
contract price & 10 billion-50 billion & 8 & 53.33 \\
yearly & $>50$ billion & 2 & 13.33 \\
\hline
\end{tabular}

3.2. Result of the Validity Test and the Reliability Test. The validity test in this paper uses a confident level of 95\% (5\% significant level) by $t_{\text {sig }}$ obtained equal to 0.514 . The test criterion is that if $t \geq t_{\text {sig }}$, then the instrument is declared valid, and vice versa. The results of the validity test for data of frequency index and severity index of each question are summarized in Tables 6 and 7.

The reliability test result for the frequency index and the severity index analyses indicate that the C-Alpha value for all risk factors (labor, materials, and equipment) is higher than 0.6 , as summarized in Tables 8 and 9 .

3.3. Risk Assessment. In the case of frequency analysis of labor risk factors, there are no "often" variables with consistent occurrence in the three study periods, and only 4 (four) "often" variables appear consistently in Period I and Period II. These variables are A1 (poor labor availability), A2 (inadequate labor capacity), A3 (poor worker discipline), and A4 (low work productivity). Although consistently appearing in the first two periods, the variables $\mathrm{A} 1, \mathrm{~A} 3$, and A4 show a declining pattern from the initial period to the next period, except A2. This condition is reasonable, while
TABLE 6: Result of the validity test of FI data.

\begin{tabular}{lcccc}
\hline $\begin{array}{l}\text { Variable } \\
\text { code }\end{array}$ & Period I & $\begin{array}{c}\text { Range of } t \\
\text { Period II }\end{array}$ & Period III & Information \\
\hline A1-A7 & $0.590-0.934$ & $0.590-0.934$ & $0.729-1.176$ & Valid \\
B1-B10 & $0.579-0.870$ & $1.489-2.258$ & $0.556-0.913$ & Valid \\
C1-C17 & $0.544-0.946$ & $0.544-0.947$ & $0.139-0.939$ & Valid \\
\hline
\end{tabular}

TABLE 7: Result of the validity test of SI data.

\begin{tabular}{lcccc}
\hline $\begin{array}{l}\text { Variable } \\
\text { code }\end{array}$ & Period I & $\begin{array}{c}\text { Range of } t \\
\text { Period II }\end{array}$ & Period III & Information \\
\hline A1-A7 & $0.536-0.831$ & $0.566-0.950$ & $0.775-0.951$ & Valid \\
B1-B10 & $0.558-0.879$ & $0.529-0.863$ & $0.573-1.000$ & Valid \\
C1-C17 & $0.517-0.919$ & $0.535-0.880$ & $0.578-0.948$ & Valid \\
\hline
\end{tabular}

TABLE 8: Result of the reliability test of data frequency.

\begin{tabular}{lcccc}
\hline \multirow{2}{*}{ Factors } & \multicolumn{3}{c}{ Reliability test results } & \multirow{2}{*}{ Information } \\
& Period I & Period II & Period III & \\
\hline Labor & 0.89 & 1.14 & 1.15 & Reliable \\
Material & 0.93 & 5.97 & 0.83 & Reliable \\
Equipment & 1.08 & 0.98 & 0.87 & Reliable \\
\hline
\end{tabular}

TABLE 9: Result of the reliability test of data severity.

\begin{tabular}{lcccc}
\hline \multirow{2}{*}{ Factors } & \multicolumn{3}{c}{ Reliability test results } & \multirow{2}{*}{ Information } \\
& Period I & Period II & Period III & \\
\hline Labor & 0.74 & 0.81 & 0.87 & Reliable \\
Material & 0.88 & 0.86 & 0.89 & Reliable \\
Equipment & 0.96 & 0.96 & 0.98 & Reliable \\
\hline
\end{tabular}

from the Period I to the next period, the threat to the lives of labors is more secure.

In the material risk factor, there are 2 (two) "often" variables such as variable of B1 (material price increase) and B2 (material delivery delay). Only B1 variable consistently appears on all three periods, except B2 variable. Although B1 is consistent, $\mathrm{B} 1$ is not a variable that affects the time risk compared to $\mathrm{B} 2$, as its variable name.

In the equipment risk factor, 3 (three) "often" variables appear in Period I, namely, C3 (delayed mobilization of equipment), C9 (fuel shortages), and C10 (difficult to access for heavy equipment). Variable B9 often occurs in Period I because of wars between parties (characteristics of conflict areas) that hinder the mobilization of heavy equipment. The results of FI analysis for three factors can be seen in Table 10 .

In case of the severity analysis for labor risk factors, only 1 (one) "high" variable and variable Al appear only in Period I (poor workforce availability). In the case of the severity analysis for material risk factors, only 1 (one) "high" variable and variable B2 appear only in Period I (material delivery delay). While for the equipment risk factors, there is no "high" variable giving impact toward time severity. The results of SI analysis for three factors can be seen in Table 11.

In the case of risk importance index, the analysis for three risk factors in all three periods analyzed is in the next section. 
TABLE 10: Result of frequency index (FI).

\begin{tabular}{|c|c|c|c|c|c|c|c|}
\hline \multirow{2}{*}{ Resources factors } & \multirow{2}{*}{ Variable code } & \multicolumn{2}{|c|}{ Period I } & \multicolumn{2}{|c|}{ Period II } & \multicolumn{2}{|c|}{ Period III } \\
\hline & & FI & Scale & FI & Scale & FI & Scale \\
\hline \multirow{7}{*}{ Labor } & A1 & 0.667 & Often & 0.640 & Often & 0.547 & Often enough \\
\hline & $\mathrm{A} 2$ & 0.667 & Often & 0.667 & Often & 0.547 & Often enough \\
\hline & A3 & 0.653 & Often & 0.627 & Often & 0.573 & Often enough \\
\hline & $\mathrm{A} 4$ & 0.640 & Often & 0.640 & Often & 0.560 & Often enough \\
\hline & A5 & 0.493 & Often enough & 0.480 & Often enough & 0.480 & Often enough \\
\hline & A6 & 0.427 & Often enough & 0.467 & Often enough & 0.453 & Often enough \\
\hline & A7 & 0.387 & Often enough & 0.387 & Often enough & 0.360 & Often enough \\
\hline \multirow{10}{*}{ Material } & $\mathrm{B} 1$ & 0.667 & Often & 0.693 & Often & 0.653 & Often \\
\hline & $\mathrm{B} 2$ & 0.653 & Often & 0.493 & Often enough & 0.507 & Often enough \\
\hline & B3 & 0.613 & Often enough & 0.493 & Often enough & 0.493 & Often enough \\
\hline & B4 & 0.387 & Often enough & 0.387 & Often enough & 0.36 & Rarely \\
\hline & B5 & 0.507 & Often enough & 0.427 & Often enough & 0.44 & Often enough \\
\hline & B6 & 0.467 & Often enough & 0.467 & Often enough & 0.427 & Often enough \\
\hline & B7 & 0.440 & Often enough & 0.373 & Rarely & 0.387 & Often enough \\
\hline & B8 & 0.453 & Often enough & 0.413 & Often enough & 0.373 & Rarely \\
\hline & B9 & 0.493 & Often enough & 0.453 & Often enough & 0.387 & Often enough \\
\hline & $\mathrm{B} 10$ & 0.347 & Rarely & 0.32 & Rarely & 0.293 & Rarely \\
\hline \multirow{17}{*}{ Equipment } & $\mathrm{C} 1$ & 0.413 & Often enough & 0.373 & Rarely & 0.373 & Rarely \\
\hline & $\mathrm{C} 2$ & 0.427 & Often enough & 0.413 & Often enough & 0.347 & Rarely \\
\hline & $\mathrm{C} 3$ & 0.640 & Often & 0.56 & Often enough & 0.413 & Often enough \\
\hline & $\mathrm{C} 4$ & 0.480 & Often enough & 0.44 & Often enough & 0.387 & Often enough \\
\hline & $\mathrm{C} 5$ & 0.573 & Often enough & 0.587 & Often enough & 0.56 & Often enough \\
\hline & C6 & 0.480 & Often enough & 0.467 & Often enough & 0.4 & Often enough \\
\hline & $\mathrm{C} 7$ & 0.493 & Often enough & 0.467 & Often enough & 0.427 & Often enough \\
\hline & $\mathrm{C} 8$ & 0.480 & Often enough & 0.52 & Often enough & 0.453 & Often enough \\
\hline & $\mathrm{C} 9$ & 0.627 & Often & 0.52 & Often enough & 0.52 & Often enough \\
\hline & $\mathrm{C} 10$ & 0.680 & Often & 0.533 & Often enough & 0.533 & Often enough \\
\hline & $\mathrm{C} 11$ & 0.453 & Often enough & 0.493 & Often enough & 0.427 & Often enough \\
\hline & $\mathrm{C} 12$ & 0.493 & Often enough & 0.467 & Often enough & 0.427 & Often enough \\
\hline & $\mathrm{C} 13$ & 0.467 & Often enough & 0.467 & Often enough & 0.467 & Often enough \\
\hline & $\mathrm{C} 14$ & 0.480 & Often enough & 0.453 & Often enough & 0.48 & Often enough \\
\hline & $\mathrm{C} 15$ & 0.480 & Often enough & 0.413 & Often enough & 0.373 & Rarely \\
\hline & $\mathrm{C} 16$ & 0.440 & Often enough & 0.453 & Often enough & 0.387 & Often enough \\
\hline & $\mathrm{C} 17$ & 0.427 & Often enough & 0.32 & Rarely & 0.373 & Rarely \\
\hline
\end{tabular}

3.3.1. Risk Importance Index for Labor Factor. Based on the calculation of the average RII (Table 12) in each period, the highest rank of variable is A1 (low availability of labor) in Period I, variable A2 (the ability of labor is less) in Period II, and variable A3 (the discipline of unfavorable workers) in Period III. The risk of A1 variable tends to decrease over the three periods.

Generally, there are 3 (three) high-score variables of RII in the labor factors. This RII of the three variables is obtained of the relative frequencies of occurrences (FI) and impact of severity (SI). The RII of high-score variables is used to analyze time risk to achieve the completion of the contract time. The problem of A1 (low availability of labor) is commonly experienced in Period I (military and political conflict), in which laborers from outside Aceh do not dare to come to work in this area. When the conflict situation decreases, the problem of labor availability can be resolved, otherwise to $\mathrm{A} 2$ (the ability of labor is less).

3.3.2. Risk Importance Index for Material Factor. Based on the calculation of the average RII (Table 13), the highest rank of the variable is B2 (material delivery delay) in Period I, variable B1 (material price increase) in Period II, and variable B2 (material delivery delay) in Period III. The risk of B2 variable tends to decrease over the three periods.

The material factors also contribute to the completion of the project according to the time target. From the three periods of the study, the risks to completion times are determined by B1 (material price increase) and B2 (material delivery delays). B1 variable (the problem of price increase) in Aceh is determined by the supply and demand aspects influencing the time transportation. During the Period II (rehabilitation and reconstruction period), there is a high increase in material demand without the availability of adequate supply. Delivery delays are also a problem considering the distribution of separate project sites and not in the economic center of a region.

3.3.3. Risk Importance Index for Equipment Factor. Based on the equipment risk factor, the variable with the highest RII in Period I is C3 (delayed mobilization of equipment), while in Periods II and III, the C5 variable (tool breakdown). The risk 
TABLE 11: Result of the severity index (SI).

\begin{tabular}{|c|c|c|c|c|c|c|c|}
\hline \multirow{2}{*}{ Factors } & \multirow{2}{*}{ Variable code } & \multicolumn{2}{|c|}{ Period I } & \multicolumn{2}{|c|}{ Period II } & \multicolumn{2}{|c|}{ Period III } \\
\hline & & SI & Scale & SI & Scale & SI & Scale \\
\hline \multirow{7}{*}{ Labor } & A1 & 0.650 & High & 0.570 & Medium & 0.490 & Medium \\
\hline & $\mathrm{A} 2$ & 0.610 & Medium & 0.610 & Medium & 0.510 & Medium \\
\hline & A3 & 0.560 & Medium & 0.530 & Medium & 0.510 & Medium \\
\hline & A4 & 0.510 & Medium & 0.490 & Medium & 0.450 & Medium \\
\hline & A5 & 0.490 & Medium & 0.450 & Medium & 0.450 & Medium \\
\hline & A6 & 0.510 & Medium & 0.450 & Medium & 0.440 & Medium \\
\hline & A7 & 0.430 & Medium & 0.400 & Medium & 0.350 & Medium \\
\hline \multirow{10}{*}{ Material } & B1 & 0.440 & Medium & 0.410 & Medium & 0.410 & Medium \\
\hline & $\mathrm{B} 2$ & 0.650 & High & 0.560 & Medium & 0.570 & Medium \\
\hline & B3 & 0.470 & Medium & 0.450 & Medium & 0.450 & Medium \\
\hline & B4 & 0.350 & Low & 0.370 & Low & 0.360 & Low \\
\hline & B5 & 0.360 & Low & 0.350 & Low & 0.370 & Low \\
\hline & B6 & 0.360 & Low & 0.400 & Medium & 0.390 & Medium \\
\hline & B7 & 0.410 & Medium & 0.370 & Low & 0.360 & Low \\
\hline & B8 & 0.440 & Medium & 0.410 & Medium & 0.400 & Medium \\
\hline & B9 & 0.470 & Medium & 0.440 & Medium & 0.390 & Medium \\
\hline & $\mathrm{B} 10$ & 0.310 & Low & 0.280 & Low & 0.370 & Low \\
\hline \multirow{17}{*}{ Equipment } & $\mathrm{C} 1$ & 0.370 & Low & 0.370 & Low & 0.370 & Low \\
\hline & $\mathrm{C} 2$ & 0.370 & Low & 0.330 & Low & 0.370 & Low \\
\hline & $\mathrm{C} 3$ & 0.610 & Medium & 0.480 & Medium & 0.520 & Medium \\
\hline & $\mathrm{C} 4$ & 0.400 & Medium & 0.370 & Low & 0.440 & Medium \\
\hline & $\mathrm{C} 5$ & 0.530 & Medium & 0.530 & Medium & 0.490 & Medium \\
\hline & C6 & 0.410 & Medium & 0.430 & Medium & 0.400 & Medium \\
\hline & $\mathrm{C} 7$ & 0.470 & Medium & 0.430 & Medium & 0.400 & Medium \\
\hline & $\mathrm{C} 8$ & 0.470 & Medium & 0.410 & Medium & 0.360 & Low \\
\hline & $\mathrm{C} 9$ & 0.530 & Medium & 0.480 & Medium & 0.450 & Medium \\
\hline & $\mathrm{C} 10$ & 0.490 & Medium & 0.450 & Medium & 0.470 & Medium \\
\hline & C11 & 0.400 & Medium & 0.440 & Medium & 0.390 & Medium \\
\hline & $\mathrm{C} 12$ & 0.470 & Medium & 0.400 & Medium & 0.390 & Medium \\
\hline & $\mathrm{C} 13$ & 0.440 & Medium & 0.450 & Medium & 0.370 & Low \\
\hline & $\mathrm{C} 14$ & 0.480 & Medium & 0.450 & Medium & 0.400 & Medium \\
\hline & C15 & 0.350 & Low & 0.290 & Low & 0.350 & Low \\
\hline & $\mathrm{C} 16$ & 0.370 & Low & 0.330 & Low & 0.330 & Low \\
\hline & $\mathrm{C} 17$ & 0.330 & Low & 0.310 & Low & 0.310 & Low \\
\hline
\end{tabular}

TABLE 12: Result of the risk importance index (RII) for labor factor.

\begin{tabular}{lcccccc}
\hline \multirow{2}{*}{ Variable code } & \multicolumn{2}{c}{ Period I } & \multicolumn{2}{c}{ Period II } & \multicolumn{2}{c}{ Period III } \\
& RII & Rank & RII & Rank & RII & Rank \\
\hline A1 & 0.434 & $\mathbf{1}$ & 0.365 & 2 & 0.268 & 3 \\
A2 & 0.407 & 2 & 0.407 & $\mathbf{1}$ & 0.279 & 2 \\
A3 & 0.366 & 3 & 0.332 & 3 & 0.297 & $\mathbf{1}$ \\
A4 & 0.326 & 4 & 0.314 & 4 & 0.252 & 4 \\
A5 & 0.242 & 5 & 0.216 & 5 & 0.216 & 5 \\
A6 & 0.218 & 6 & 0.210 & 6 & 0.199 & 6 \\
A7 & 0.167 & 7 & 0.155 & 7 & 0.126 & 7 \\
\hline
\end{tabular}

of C3 variables tends to decrease from Period $1(0.390)$ to the next periods (Period 2 (0.269) and Period 3 (0.215)). Based on this condition, it can be seen that these variables give an essential role in the delay of construction project work in the three phases of study in Aceh Province. The results of RII analysis can be seen in Table 14 .

The delay problems in the project completion in this factor arise due to the variables of C3 (delayed mobilization of equipment) and C5 (tool breakdown). This delay mobilization due to limited access of contractor companies to project sites
TABLE 13: Result of the risk importance index (RII) for material factor.

\begin{tabular}{lllllll}
\hline \multirow{2}{*}{ Variable code } & \multicolumn{2}{l}{ Period I } & \multicolumn{2}{l}{ Period II } & \multicolumn{2}{l}{ Period III } \\
& RII & Rank & RII & Rank & RII & Rank \\
\hline B1 & 0.294 & 2 & 0.284 & $\mathbf{1}$ & 0.268 & 2 \\
B2 & 0.425 & $\mathbf{1}$ & 0.276 & 2 & 0.290 & $\mathbf{1}$ \\
B3 & 0.288 & 4 & 0.222 & 3 & 0.222 & 3 \\
B4 & 0.136 & 10 & 0.143 & 9 & 0.130 & 10 \\
B5 & 0.183 & 7 & 0.150 & 7 & 0.163 & 5 \\
B6 & 0.168 & 9 & 0.187 & 5 & 0.167 & 4 \\
B7 & 0.180 & 8 & 0.138 & 10 & 0.140 & 9 \\
B8 & 0.199 & 6 & 0.169 & 6 & 0.150 & 8 \\
B9 & 0.232 & 5 & 0.200 & 4 & 0.151 & 7 \\
B10 & 0.108 & 11 & 0.090 & 11 & 0.108 & 11 \\
B11 & 0.294 & 2 & 0.150 & 7 & 0.163 & 5 \\
\hline
\end{tabular}

during this period is emerged during Period I (military and political conflict periods). In the two subsequent periods, the problems, generally, arise due to the inability of firms to overcome the equipment damage along with the increasing and workload of equipment need. 
TABLE 14: Result of the risk importance index (RII) for equipment factor.

\begin{tabular}{|c|c|c|c|c|c|c|}
\hline \multirow{2}{*}{ Variable code } & \multicolumn{2}{|c|}{ Period I } & \multicolumn{2}{|c|}{ Period II } & \multicolumn{2}{|c|}{ Period III } \\
\hline & RII & Rank & RII & Rank & RII & Rank \\
\hline $\mathrm{C} 1$ & 0.153 & 16 & 0.138 & 14 & 0.138 & 13 \\
\hline $\mathrm{C} 2$ & 0.158 & 15 & 0.136 & 15 & 0.128 & 15 \\
\hline $\mathrm{C} 3$ & 0.390 & 1 & 0.269 & 2 & 0.215 & 4 \\
\hline $\mathrm{C} 4$ & 0.192 & 11 & 0.163 & 12 & 0.170 & 8 \\
\hline $\mathrm{C} 5$ & 0.304 & 4 & 0.311 & 1 & 0.274 & 1 \\
\hline C6 & 0.197 & 10 & 0.201 & 9 & 0.160 & 12 \\
\hline $\mathrm{C} 7$ & 0.232 & 5 & 0.201 & 9 & 0.171 & 7 \\
\hline $\mathrm{C} 8$ & 0.226 & 8 & 0.213 & 6 & 0.163 & 11 \\
\hline $\mathrm{C} 9$ & 0.332 & 3 & 0.250 & 3 & 0.234 & 3 \\
\hline $\mathrm{C} 10$ & 0.333 & 2 & 0.240 & 4 & 0.251 & 2 \\
\hline $\mathrm{C} 11$ & 0.181 & 12 & 0.217 & 5 & 0.167 & 9 \\
\hline $\mathrm{C} 12$ & 0.232 & 5 & 0.187 & 11 & 0.167 & 9 \\
\hline $\mathrm{C} 13$ & 0.205 & 9 & 0.210 & 7 & 0.173 & 6 \\
\hline $\mathrm{C} 14$ & 0.230 & 7 & 0.204 & 8 & 0.192 & 5 \\
\hline $\mathrm{C} 15$ & 0.168 & 13 & 0.120 & 16 & 0.131 & 14 \\
\hline $\mathrm{C} 16$ & 0.163 & 14 & 0.150 & 13 & 0.128 & 15 \\
\hline $\mathrm{C} 17$ & 0.141 & 17 & 0.099 & 17 & 0.116 & 17 \\
\hline
\end{tabular}

TABle 15: Ten potential rankings in all three periods.

\begin{tabular}{lcccccccc}
\hline \multirow{2}{*}{ Risk factors } & \multirow{2}{*}{ Variable code } & \multicolumn{2}{c}{ Period I } & \multicolumn{2}{c}{ Period II } & \multicolumn{2}{c}{ Period III } & \multirow{2}{*}{ Top ten variables in all periods } \\
& & RII & Rank & RII & Rank & RII & Rank & 1 \\
Labor & A1 & 0.434 & 1 & 0.365 & 2 & 0.268 & 5 & 2 \\
Material & B2 & 0.425 & 2 & 0.276 & 7 & 0.290 & 2 & 3 \\
Labor & A2 & 0.407 & 3 & 0.407 & 1 & 0.279 & 3 & 4 \\
Labor & A3 & 0.366 & 5 & 0.332 & 3 & 0.297 & 1 & 5 \\
Equipment & C10 & 0.333 & 6 & 0.240 & 10 & 0.251 & 8 & 7 \\
Equipment & C9 & 0.332 & 7 & 0.250 & 9 & 0.234 & 9 & 7 \\
Labor & A4 & 0.326 & 8 & 0.314 & 4 & 0.252 & 7 & 9 \\
Equipment & C5 & 0.304 & 9 & 0.311 & 5 & 0.274 & 4 & 6 \\
Material & B1 & 0.294 & 10 & 0.284 & 6 & 0.268 & 6 & 10 \\
Material & B3 & 0.288 & 12 & 0.222 & 11 & 0,222 & 10 & \\
\hline
\end{tabular}

3.3.4. Risk Assessment of Resources Factor for All Periods in Aceh. In this subsection, risk assessment analysis in the three periods in Aceh Province is based on the resources factor of a combination of labor, materials, and equipment. In Table 15, the top ten variables of 35 risk assessment variables are shown.

The top ten variables are A1, A2, A4, B2, B3 [31], B3 [32], A2, B1, B2 [33], and A1, A2, A4, B1, B2, B3, C5 [34]. Based on these top ten variables, seven variables are related to variables in other studies from other regions or countries. While the rest three variables become the contractor's risk characteristics from this research case study (A3, C9, and $\mathrm{C} 10)$.

\section{Conclusions}

This study shows the result of assessment related to risk assessment by using the indicator of frequency, severity, and risk importance index. The project risk is the superposition of RII on all risk variables. Each variable is a function of frequency and severity. Both frequency and severity influence high and low risks. The RII analysis is used as an input to assess the most dominant risk of cost, time, and quality.
Based on the labor risk factors, the most dominant time risk variable occurring in Period I is the inadequate availability of labor; in Period II, the ability of the workforce is lacking; and in Period III, experience/expertise of the contractor is lacking. From the material risk factor, the most dominant time risk variable occurs in Period I, and Period III is the delay of material delivery, while in Period II, the material price increase. Based on RII analysis result from the equipment risk factor, it can be concluded that the most dominant time risk variable occurring in Period I is the delay in the mobilization of equipment, while in Period I and II, equipment malfunction.

We have analyzed 35 variables which were categorized into three factors of variables which are tested in three periods providing different risk characteristics, both concerning risk probability and risk impact. Based on the variable, it has been concluded that ten variables as the most dominant risks that arise simultaneously in all three periods. Four variables, namely, low labor availability (A1), the ability of the labor is lacking (A2), the discipline of unfavorable labor (A3), and low labor productivity (A4), are derived from labor factors. Three variables, namely, the increase in material prices (B1), delay in material delivery (B2), and 
theft of material (B3), are derived from material factors. While the three variables are device damage (C5), fuel scarcity (C9), and the difference between difficulties to access heavy equipment $(\mathrm{C} 10)$ come from the equipment factor. The ten dominant variables, three of which are $\mathrm{A} 3, \mathrm{C} 9$, and $\mathrm{C} 10$ are derived from the characteristics of the three periods in this study, while seven variables are also related to risk variables in other regions or countries, namely, A1, A2, A4, $\mathrm{B} 1, \mathrm{~B} 2, \mathrm{~B} 3$, and $\mathrm{C} 5$.

\section{Data Availability}

The data used to support the findings of this study are available from the corresponding author upon request.

\section{Conflicts of Interest}

The authors declare that they have no conflicts of interest.

\section{Acknowledgments}

We would like to thank both the research team and respondents for supporting the research.

\section{References}

[1] M. Clayton, Risk Happens, Marshall Cavendish, London, UK, 2011.

[2] PMI, A Guide to Project management Body of Knowledge (PMBOK@Guide), Project Management Institute, Newtown Square, PA, USA, 4th edition, 2008.

[3] A. I. I. Diéguez, A. S. Cazorla, and R. A. Luque, "Risk management in Megaprojects," Procedia-Social and Behavioral Sciences, vol. 119, pp. 407-416, 2014.

[4] F. Fachrurrazi, "Project risk patterns: a comparison accross three periods," International Journal on Advanced Science, Engineering and Information Technology, vol. 8, no. 2, p. 112, 2018.

[5] A. Mills, "A systematic approach to risk management for construction," Structural Survey, vol. 19, no. 5, pp. 245-252, 2001.

[6] C. F. Gray and E. W. Larson, Project Management: The Managerial Process, Mc Graw-Hill, Singapore, 2000.

[7] S. M. Sádaba, A. P. Ezcurdia, A. M. Lazcano, and P. Villanueva, "Project risk management methodology for small firms," International Journal of Project Management, vol. 32, no. 2, pp. 327-340, 2014.

[8] A. Albogamy, N. Dawood, and D. Scott, "A risk management approach to address construction delays from client aspect," Computing in Civil and Building Engineering, pp. 1497-1505, 2014.

[9] G. J. Kikwasi, "Causes and effects of delays and disruptions in construction projects in Tanzania," Australasian Journal of Construction Economics and Building, vol. 1, no. 2, pp. 52-59, 2012.

[10] N. Banaitiene and A. Banaitis, "Risk management in construction projects," Risk Management-Current Issues and Challenges, InTech, London, UK, 2012.

[11] A. Vafadarnikjoo, M. Mobin, and S. M. A. K. Firouzabadi, "An intuitionistic fuzzy-based DEMATEL to rank risks of construction projects," in Proceedings of the 2016 International Conference on Industrial Engineering and Operations Management, Detroit, Michigan, USA, September, 2016.
[12] H. Kerzner, Project Management, John Willey and Sons, New York, NY, USA, 10th edition, 2009.

[13] W. Mark, P. E. Cohen, and R. P. Glen, "Project risk identification and management," AACE International Transaction, INT.01.1-5, 2004.

[14] P. Rezakhani, "A review of fuzzy risk assessment models for construction projects," Slovak journal of Civil engineering, vol. 20, no. 3, pp. 35-40, 2012.

[15] I. Mahamid, "Risk matrix for factors affecting time delay in road construction projects: owner's perspective," Engineering, Construction and Architectural Management, vol. 18, no. 6, pp. 609-617, 2011.

[16] Douglas and Hubbard, The Failure of Risk Management: Why It's Broken and How to Fix It, John Wiley \& Sons, New York, NY, USA, 2009.

[17] A. A. R. Karimi, N. Mousavi, S. F. Mousavi, and S. B. Hosseini, "Risk assessment model selection in the construction industry," Expert System with Applications, vol. 38, no. 8, pp. 9105-9111, 2011.

[18] O. Taylan, A. O. Bafail, R. M. Abdulaal, and M. R. Kabli, "Construction projects selection and risk assessment by fuzzy AHP and fuzzy TOPSIS methodologies," Applied Soft Computing, vol. 17, pp. 105-116, 2014.

[19] P. Zeccola, "Dividing disasters in Aceh, Indonesia: separatist conflict and tsunami, human rights and humanitarianism," Disasters, vol. 35, no. 2, pp. 308-328, 2010.

[20] S. Husin, Abdullah, M. Riza, M. Afifuddin, and P. Zalbania, "Risk level of labor factors, materials and equipment on construction projects in Aceh Province," in Proceedings of National Conference of Civil Engineering, pp. 26-27, Atma Jaya University of Yogyakarta, October 2016.

[21] S. Husin Mubarak and Syarafina, "External risk on construction project implementation in Aceh Province," in Proceedings of National Conference of Civil Engineering, pp. 26-27, Atma Jaya University of Yogyakarta, Yogyakarta, Indonesia, October 2016.

[22] F. Maulina, M. Jamil Fachrurrazi, and H. Amalia, "Cost risk comparison to construction contractors in three periods in Aceh Province," in Proceedings of National Conference of Civil Engineering, pp. 26-27, Atma Jaya University of Yogyakarta, Yogyakarta, Indonesia, October 2016.

[23] M. Nurisra, N. Malahayati, and I. Sari, "Project construction risks stemming from contract and planning factors in Aceh Province," in Proceedings of National Conference of Civil Engineering, pp. 26-27, Atma Jaya University of Yogyakarta, Yogyakarta, Indonesia, October 2016.

[24] Tripoli, A. T. Bulba, Fachrurrazi, and C. A. W. Mastura, "Identify the risk of implementation at construction project in Aceh Province," in Proceedings of National Conference of Civil Engineering, pp. 26-27, Atma Jaya University of Yogyakarta, Yogyakarta, Indonesia, October 2016.

[25] S. Husin, Abdullah, M. Riza, and M. Afifuddin, "Construction cost impact related to manpower, material, and equipment factors in contractor firms perspective," AIP Conference Proceedings, vol. 1903, no. 1, 2017.

[26] Mubarak, S. Husin, and M. Oktaviati, "External risk factors affecting construction costs," AIP Conference Proceedings, vol. 1903, no. 1, 2017.

[27] M. J. de Smith, Statistical Analysis Handbook-A Web-Based Statistics Resource, The Winchelsea Press, Winchelsea, UK, 2015.

[28] J. M. Bland and D. G. Altman, "Statistics notes: cronbach's alpha,” BMJ, vol. 314, no. 7080, p. 572, 1997.

[29] T. Jeremias and S. Freyke, "Risk analysis on housing construction project in Manado City," Journal of Media 
Engineering Sciences Sam Ratulangi University, vol. 1, no. 1, pp. 29-37, 2011.

[30] M. Z. Abd. Majid and R. Mc Caffer, "Assessment of work performance of maintenance contractors in Saudi Arabia," Journal of Management in Engineering, vol. 13, no. 5, p. 91, 1997.

[31] M. S. B. A. Abd El-Karim, O. A. M. El-Nawawy, and A. M. Abdel-Alim, "Identification and assessment of risk factors affecting construction projects," Journal of Housing and Building National Research Center, vol. 18, no. 9, pp. 72-77, 2015.

[32] Z. Sigmund and M. Radujkovic, "Risk breakdown structure for construction projects on existing buildings," Procedia Social and Behavioral Sciences, vol. 119, pp. 894-901, 2014.

[33] L. M. Khodeir and A. H. M. Mohamed, "Identifying the latest risk probabilities affecting construction projects in Egypt according to political and economic variables," Journal of Housing and Building National Research Center, vol. 11, no. 1, pp. 129-135, 2014.

[34] S. Iqbal, R. M. Choudhry, K. Holschemacher, A. Ali, and J. Tamosaitiene, "Risk management in construction projects," Technological and economic development of economy, vol. 21, no. 1, pp. 65-78, 2015. 


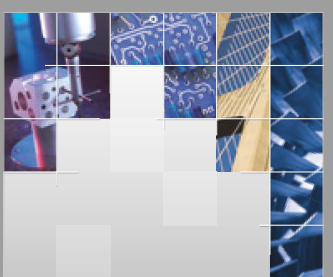

\section{Enfincering}
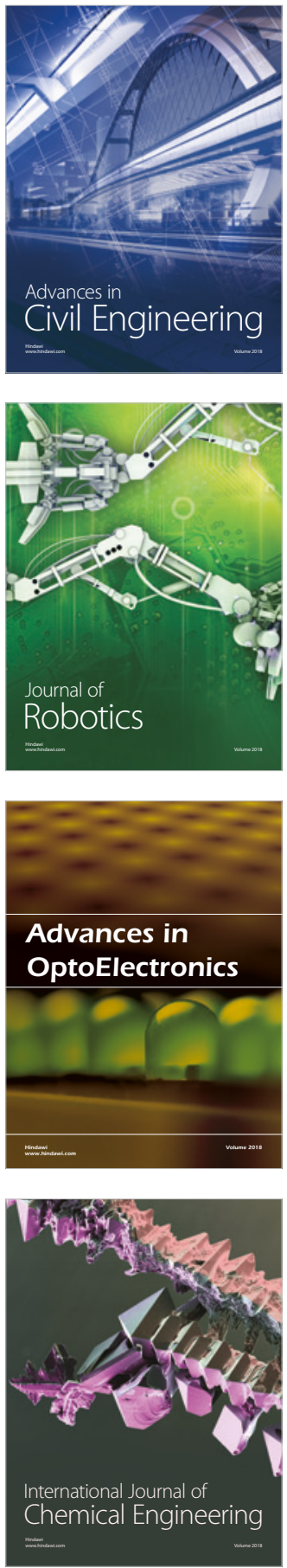

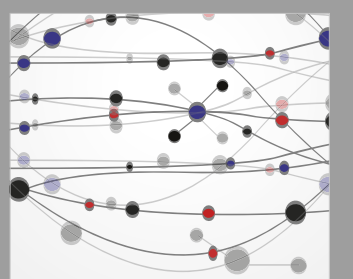

\section{Rotating \\ Machinery}

The Scientific World Journal

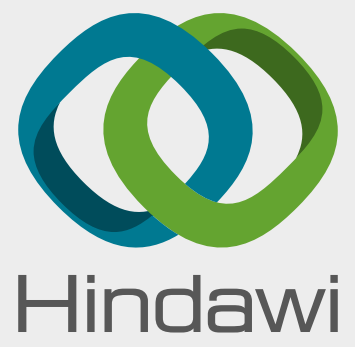

Submit your manuscripts at

www.hindawi.com
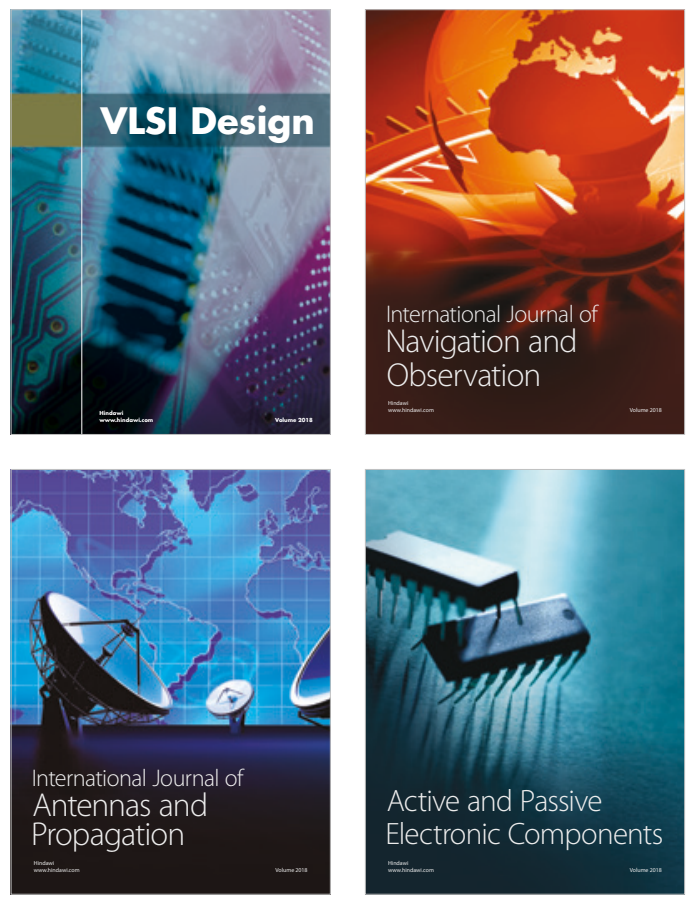
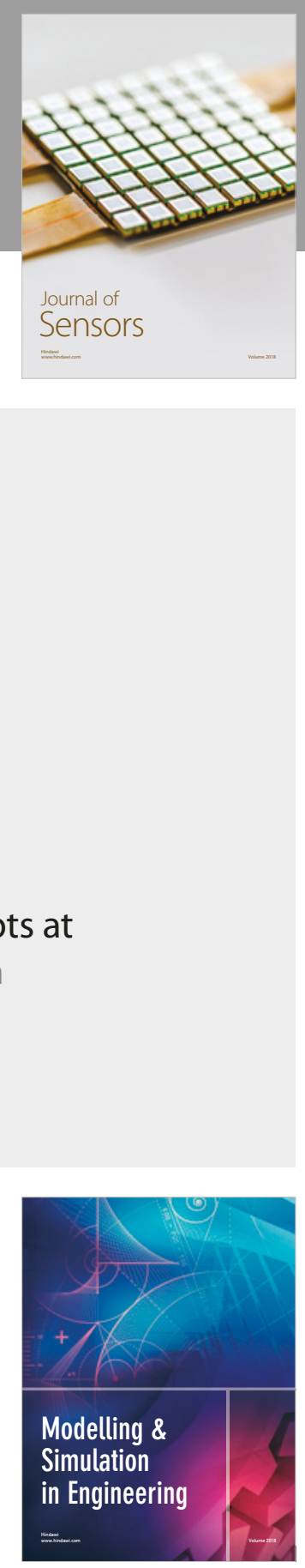

\section{Advances \\ Multimedia}
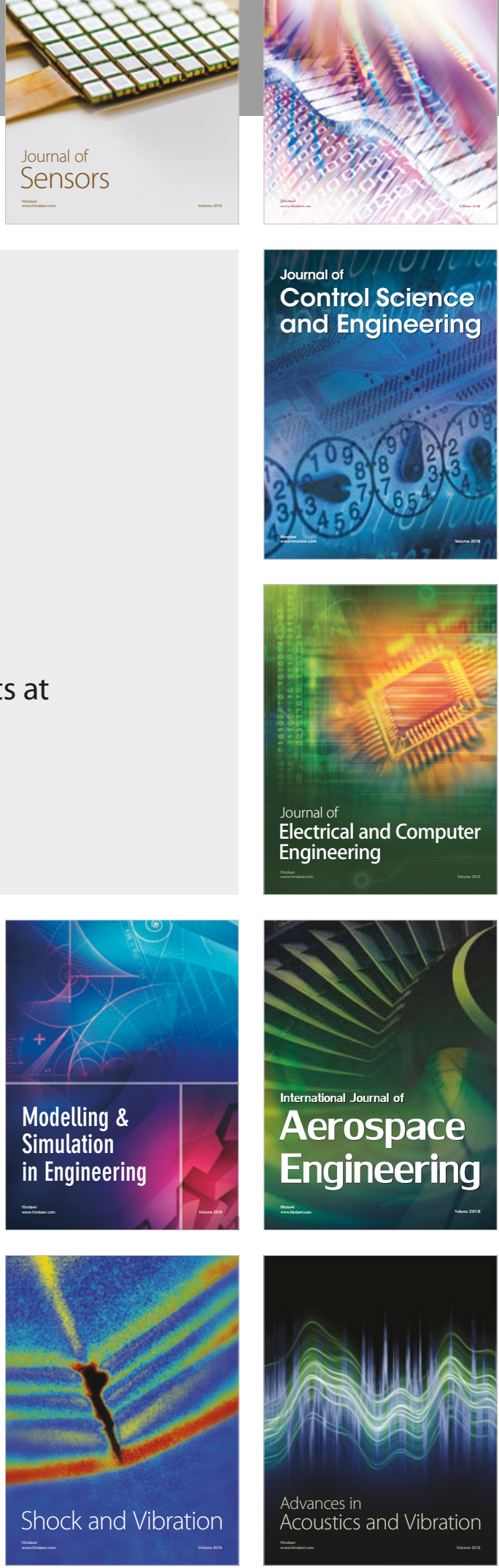